\title{
$\gamma$-Aminobutyrohydroxamate resins as stationary phases of chelation ion chromatography
}

\author{
Chuen-Ying Liu*, N-Ming Lee, Jian-Lian Chen \\ Department of Chemistry, National Taiwan University, Taipei, Taiwan
}

Received 24 December 1997; received in revised form 11 March 1998; accepted 7 April 1998

\begin{abstract}
$\gamma$-Aminobutyrohydroxamate resin and its derivatives were prepared and employed as stationary phases in chelation ion chromatography for the simultaneous determination of trace metal ions in sea water and biological sample. The method consists of preconcentration of a $25 \mathrm{ml}$ sea water or biological sample on a $\gamma$-aminobutyrohydroxamate resin column; alkali and alkaline earth metal ions are removed from the resin with potassium nitrate $(0.01 \mathrm{M})$ solution, the metal ions are eluted with oxalic acid $(0.03 \mathrm{M}, \mathrm{pH}$ 2.6) and separated on a Dionex CS-5 column, followed by postcolumn derivatization with 4(2pyridylazo)resorcinol and spectrophotometric detection at $495 \mathrm{~nm}$. The concentration and separation steps are automated. The method shows good linearity for $\mathrm{Co}(\mathrm{II}), \mathrm{Cu}(\mathrm{II}), \mathrm{Mn}(\mathrm{II}), \mathrm{Ni}(\mathrm{II})$ and $\mathrm{Zn}(\mathrm{II})$ ranging from 0.5 to $10 \mathrm{ng} \mathrm{ml}^{-1}$ and that for $\mathrm{Cd}(\mathrm{II})$ ranging from 2 to $40 \mathrm{ng} \mathrm{ml}^{-1}$. The detection limits for $\mathrm{Co}(\mathrm{II}), \mathrm{Cd}(\mathrm{II}), \mathrm{Cu}(\mathrm{II}), \mathrm{Mn}(\mathrm{II}), \mathrm{Ni}(\mathrm{II})$ and $\mathrm{Zn}$ (II) are $0.4,1.2,0.5,0.4,0.8$ and $0.3 \mathrm{ng} \mathrm{ml}^{-1}$, respectively. The analytical reliability of the proposed method was evaluated by analyzing oyster tissue standard reference material (NIST, SRM 1566a). (C) 1998 Elsevier Science B.V. All rights reserved.
\end{abstract}

Keywords: Chelation ion chromatography; $\gamma$-Aminobutyrohydroxamate resin; Preconcentration; Transition metal ions; Complex matrix samples

\section{Introduction}

Despite advances in instrumentation and microcomputer technology, the determination of trace elements in complex matrices remains one of the most challenging areas of analytical chemistry. In general, high ionic strength matrices usually interfere with chromatographic separations and degrade the detection limits for many transition metals. To determine

\footnotetext{
*Corresponding author. Fax: +886 2 23636359; e-mail: cyliu@ccms.ntu.edu.tw
}

trace elements in complex matrices, a separation and/ or preconcentration step is frequently necessary. The separation eliminates sample matrix components that may interfere with the subsequent analytical measurements, while preconcentration concentrates the analytes of interest from a large volume of sample. Selective polymer resins, including chelating resins and reagent-impregnated resins, have been widely applied as stationary phases for the complexation in chromatographic separation of metal ions. By using selective ion exchange materials, analytes can be concentrated, while commonly interfering materials, such as, alkali and alkaline earth metals and anions are 
partly or completely eliminated. The selectivity of these chelating substrates can be further controlled by altering the conditional stability constants of the chelates being formed, through control of the $\mathrm{pH}$ and concentration of the eluent.

Complexation ion chromatography (chelation ion chromatography, CIC) includes all ion chromatographic modes in which complexation is exploited for the separation and detection of metal ions in different ways. Several reports showing examples of such applications have already been published [1-14]. The CIC technique was first introduced by Kingston et al. [9], who claimed that a higher cross-linked resin containing iminodiacetic acid functional groups and not Chelex-100 was suitable for use at elevated pressure, providing reliable and reproducible analysis of complex matrix samples. A recent review by Timerbaev and Bonn illustrates the overview of developments and trends of CIC in trace metal analysis [7]. A number of selected chelating dyes have been impregnated into high performance substrates by Jones et al. producing a range of chelating columns for the separation of transition metal ions in calcium-containing matrices [10], coastal sea water [11], offshore oil-well brines [12] and the determination of A1(III) in sea water [3]. Nesterenko and Jones also reported a single-column method of CIC for analysis trace metals in complex samples [14].

The selectivity of chelating resin is attributed mainly to the nature of the immobilized ligand on the base matrix. In the previous work, the coordination behavior of a polymer-bound $\gamma$-aminobutyrohydroxamate resin and its derivatives has been studied [1517]. The aim of the present investigation was to assess the potential of each particular chelating resin for the concentration and separation of complex matrix samples. The comparison of their applicability to the determination of lanthanides in complex matrix samples has been reported [4]. Since, the resins exhibit strongly complexing abilities for different transition metals and form kinetically labile complexes, as well as having properties which ensure the reversible sorption of metal ions, they were investigated to determine their potential as a preconcentrator and separation column for the determination of traces amounts of transition metal ions in sea water and biological samples.

\section{Experimental}

\subsection{Apparatus}

Trace analyses were carried out with an ion chromatography system (Model 4000i, Dionex, Sunnyvale, CA) which includes a gradient pump, UVvisible spectrophotometer and an integrator (Data Jet, Spectra Physics, Santa Clara, CA). The chromatographic system was assembled as in the previous work [4], in which two metal-free valves were used. One served to convey the eliminating solution or cleaning solution, the other was for the sample solution. A switching valve was installed to control the sequence of solutions in the system. Separations were achieved on a home-made guard, concentrator and separator column. The guard column and the concentrator column $(10 \times 4 \mathrm{~mm}$ i.d. $)$ consisted of $\gamma$-aminobutyrohydroxamate resin (P13) (230-325 mesh, 8\% cross linking), to permit simultaneous preconcentration and matrix elimination. $\gamma$-Aminobutyrohydroxamate resin (P13), $N$-methyl- $\gamma$-aminobutyrohydroxamate resin $(N$ methyl-P13), $O$-methyl- $\gamma$-aminobutyrohydroxamate resin $(O$-methyl-P13) and an IonPac CS-5 column (Dionex) were investigated for the separation of transition metal ions.

A pH meter (Radiometer, PHM 61, Copenhagen, Denmark) was used to measure the $\mathrm{pH}$ of the solution.

\subsection{Reagents}

All eluents and standards were prepared from analytical reagent grade (Merck, Darmstadt, Germany) and pure water $(18 \mathrm{M} \Omega \mathrm{cm})$ (Milli-Q Ultra Pure Water System, Millipore, Belford, MA) under a class 100 laminar flow hood. The stock solutions (ca. 0.1 M) of metal ions were prepared by dissolving an appropriate amount of the respective metal salt in sub-boiling distilled nitric acids, diluting with pure water, adjusting to $\mathrm{pH} 1.6$ and storing in polyethylene bottles. The concentration of metal ion was verified by EDTA titration. Postcolumn reagent solutions $\left(6 \times 10^{-5} \mathrm{M}\right)$ were prepared by dissolving 4(2-pyridylazo)resorcinol (PAR) (Merck) in ammonia-ammonium buffer $(0.3 \mathrm{M}, \mathrm{pH} 10)$ and storage in plastic in the dark. Stock solutions of eluents $(0.01 \mathrm{M})$ were diluted and passed through a membrane filter of $0.45 \mu \mathrm{m}$ pore size (Gelman Science, Tokyo) and degassed by sonifica- 
tion with a Branson ultrasonic cleaner (Yamato, Tokyo) prior to use. All vessels were cleaned prior to use. They were washed sequentially with a detergent solution, soaked in 10\% nitric acid overnight and washed three times with pure water. Metal-free sea water was prepared as in the previous paper [4].

\subsection{Working standards}

The stock standards were diluted to the approximate concentration range of the samples to be analyzed, just prior to analysis.

\subsection{Synthesis of the chelating resins}

The detailed procedures for the preparation of $\gamma$ aminobutyrohydroxamate resin (P13), N-methyl- $\gamma$ aminobutyrohydroxamate resin ( $N$-methyl-P13) and $O$-methyl- $\gamma$-aminobutyrohydroxamate resin $(O$ methyl-P13) have already been reported [15-17].

\subsection{Chromatograph preparation and operation}

The ion chromatograph used was a metal-free system for the entire flow path. Trace metal impurities were removed from the chromatographic system by flushing the flow path, pumps, and columns with sulfuric acid $\left(1 \mathrm{M}, 100 \mathrm{ml}\right.$ ) (flow rate $2-3 \mathrm{ml} \mathrm{min}^{-1}$ ) The system was rinsed with deionized water and conditioned with the appropriate buffer prior to use.

\subsection{Sea water samples}

Sea water samples from the coast of the western Pacific Ocean were supplied by Prof. S.C. Pai of National Taiwan University. The samples were stored at $4^{\circ} \mathrm{C}$ in polypropylene bottles.

\subsection{Sample decomposition}

The oyster tissue (NIST, SRM 1566a) was digested in a closed system. For the digestion, $0.1 \mathrm{~g}$ sample together with $3.0 \mathrm{ml}$ of concentrated nitric acid (purified by sub-boiling distillation) was added to a PTFE vessel with oven digestion $\left(150^{\circ} \mathrm{C}\right)$ for $30 \mathrm{~min}$. Under this condition, the oxidizing power of the acid is significantly increased, and contamination, loss of volatile elements and dissolution time are reduced.
After digestion, the sample was cooled and excess acid was removed by vacuum evaporation. The residue was then diluted with pure water followed by filtration through a $0.45 \mu \mathrm{m}$ filter (Millipore) and transferred into a PTFE vessel for measurement. All sample solution were prepared in a clean bench, providing a class 100 working environment.

\section{Results and discussion}

\subsection{Selectivity of resin ligands with similar structures}

$\gamma$-Aminobutyrohydroxamate resin $(\mathrm{P} 13)$ and its derivatives ( $N$-methyl-P13 and $O$-methyl-P13) exhibited the properties of high metal capacity, fast kinetics and highly selectivity for transition metal ions [1517]. At $\mathrm{pH}$ values $>3$, most of the transition metals are strongly retained by these resins, while, the alkali and alkaline earth metals are scarcely retained. The retention behavior of a $\mathrm{Cd}(\mathrm{II}) \quad\left(4.4 \mu \mathrm{g} \mathrm{ml}^{-1}\right)$ Fe(III) $\quad\left(0.6 \mu \mathrm{g} \mathrm{ml}^{-1}\right)-\mathrm{Mn}(\mathrm{II}) \quad\left(1.0 \mu \mathrm{g} \mathrm{ml}^{-1}\right)-\mathrm{Zn}$ (II) $\left(0.7 \mu \mathrm{g} \mathrm{ml}^{-1}\right)$ mixture was studied, when the resin column was eluted with oxalic acid $(3 \mathrm{mM}, \mathrm{pH}$ 4.0). The retention times for the P13 resin column decreased in the order $\mathrm{Cd}\left(t_{\mathrm{R}}>70 \mathrm{~min}\right)>\mathrm{Mn}$ $\left(t_{\mathrm{R}}=55 \mathrm{~min}\right)>\mathrm{Zn}\left(t_{\mathrm{R}}=12 \mathrm{~min}\right)>\mathrm{Fe}\left(t_{\mathrm{R}}=2 \mathrm{~min}\right)$. Those for the $N$-methyl-P13 resin column decreased in the order $\mathrm{Cd}\left(t_{\mathrm{R}}>60 \mathrm{~min}\right)>\mathrm{Mn}\left(t_{\mathrm{R}}=35 \mathrm{~min}\right)>\mathrm{Zn}$ $\left(t_{\mathrm{R}}=11 \mathrm{~min}\right)>\mathrm{Fe}\left(t_{\mathrm{R}}=2 \mathrm{~min}\right)$ and for the $O$-methyl$\mathrm{P} 13$ resin column $\mathrm{Cd}\left(t_{\mathrm{R}}>40 \mathrm{~min}\right)>\mathrm{Mn}\left(t_{\mathrm{R}}=19 \mathrm{~min}\right)>$ $\mathrm{Zn}\left(t_{\mathrm{R}}=5 \mathrm{~min}\right)>\mathrm{Fe}\left(t_{\mathrm{R}}=2 \mathrm{~min}\right)$. As investigated previously, the $\mathrm{p} K_{\mathrm{a}}$ value of $\mathrm{P} 13$ is larger than that of $N$ methyl-P13 $[15,16]$, in a similar manner to the monomeric acetohydroxamic acid with respect to $N$-methylacetohydroxamic acid [18]. The results clearly illustrate that, any change in the substituent of the hydroxamate group had pronounced effects on the retention time of the analytes. The elution order of metal ions from the resin columns was somewhat surprising, since, one would expect that iron should be able to interact more strongly than cadmium, zinc and manganese. The discrepancy was accounted for by the competitive complexation reaction between oxalic acid and resin ligand toward the metal ions, since the formation constants of oxalic acid toward these metal ions decrease in the order: Fe(III) (log 
Table 1

Formation constants of metal complexes with organic ligands ${ }^{\mathrm{a}}$

\begin{tabular}{|c|c|c|c|c|c|}
\hline \multirow[t]{2}{*}{ Metal ion } & \multicolumn{5}{|l|}{$\log K_{1}$} \\
\hline & P13 resin ${ }^{b}$ & Oxalic acid ${ }^{c}$ & Tartaric acid ${ }^{\mathrm{c}}$ & Citric acid ${ }^{c}$ & Ethylene diamine ${ }^{\mathrm{c}}$ \\
\hline $\mathrm{H}\left(\mathrm{p} K_{n}\right)$ & 9.4 & $3.82 ; 1.04$ & $3.95 ; 2.82$ & $5.69 ; 4.35 ; 2.87$ & $9.89 ; 7.08$ \\
\hline $\mathrm{Cd}(\mathrm{II})$ & 7.8 & $2.75^{\mathrm{d}}$ & $2.8^{\mathrm{f}}$ & 3.75 & 5.45 \\
\hline $\mathrm{Co}(\mathrm{II})$ & 8.8 & 3.84 & 2.19 & 5.00 & 5.6 \\
\hline $\mathrm{Cu}(\mathrm{II})$ & 8.9 & 4.84 & 3.39 & 5.90 & 10.54 \\
\hline $\mathrm{Fe}(\mathrm{III})$ & 9.7 & 7.53 & 6.49 & 11.50 & - \\
\hline $\mathrm{Mn}(\mathrm{II})$ & 7.4 & 3.20 & 2.49 & 4.15 & 2.67 \\
\hline $\mathrm{Ni}(\mathrm{II})$ & 7.4 & $5.16^{\mathrm{e}}$ & 2.06 & 5.40 & 7.35 \\
\hline $\mathrm{Zn}(\mathrm{II})$ & 7.9 & 3.88 & 2.68 & 4.98 & 5.7 \\
\hline
\end{tabular}

a Ionic strength: 0.1 M; ${ }^{\mathrm{b}}$ Ref. [15,16]; ${ }^{\mathrm{c}}$ Ref. [18]; ${ }^{\mathrm{d}}$ Ionic strength: $1.0 \mathrm{M}$; ${ }^{\mathrm{e}}$ Ionic strength: 0 M; ${ }^{\mathrm{f}}$ Ref. [20].

$\left.K_{1}=7.53\right)>\mathrm{Zn}(\mathrm{II})\left(\log K_{1}=3.88\right)>\mathrm{Mn}(\mathrm{II})(\log$ $\left.K_{1}=3.20\right)>\mathrm{Cd}(\mathrm{II})\left(\log K_{1}=2.75\right)$ [18]. Although, the complexing abilities of the resin ligands toward the metal ions are larger than that of oxalic acid (Table 1), significant alterations in the retention order according to the elution conditions would be expected. The selectivity series is also the same as that expected from the sorption and metal capacity of these resins $[15,16]$. Additionally, the $O$-methyl-P13 resin column seems the most promising as a separator as a consequence of the steric hindrance of the $O$-methyl group.

In order to demonstrate the practical applicability of the prepared resin column, preliminary chromatograms for the separation of a zinc $\left(5 \mu \mathrm{g} \mathrm{ml}^{-1}\right)$-cadmium $\left(4 \mu \mathrm{g} \mathrm{ml}^{-1}\right)$ mixture in the presence of other chelating agents, such as, humic acid, ascorbic acid, EDTA, thiourea and glycine, or of sodium chloride with hydroxamate resin columns $(250 \times 3 \mathrm{~mm}$ i.d. $)$ were obtained. Elution could be achieved via a mixture of citric acid $(1 \mathrm{mM})$, tartaric acid $(1 \mathrm{mM})$ and sodium nitrate $(10 \mathrm{mM})$ or oxalic acid $(1 \mathrm{mM})$ and sodium nitrate $(10 \mathrm{mM})$. EDTA and ascorbic acid were used to simulate a powerful chelating agent and reducing agent, respectively, and humic acid was taken as a representative of colloidal substances with a complicated structure and unknown molecular mass. Among the resin columns studied, P13 resin displayed a lesser interference than the others. With the addition of ascorbic acid, thiourea or glycine (each $2 \mathrm{mM}$ ), both peak height and shape are rather similar to the pure zinc and cadmium mixture. But, the peak height decreased with increasing concentration of humic acid or EDTA, with maximum tolerated concentrations of $10 \mu \mathrm{g} \mathrm{ml}^{-1}$ and $1 \times 10^{-5} \mathrm{M}$, respec- tively, for a relative standard deviation of 5\%. A stronger competitive reaction between these ligands and the post-column reagent (PAR) might explain the phenomena to a certain extent. Since, the concentrations of these substances in natural water are much lower than the tested values [19], interferences from them in real samples could be neglected. However, pretreatment by UV digestion may be necessary in the case of higher levels of humic acid or other chelating agents. Further, a comparison of the separation of metal ions in pure and sea water with the resin column was made. Even better separation and higher peaks for the analytes were achieved in sea water than in pure water through use of the $N$-methyl-P13 resin column (Fig. 1). There was a correlation of the high selectivity of this resin to the transition metal.

\subsection{Elimination of sample matrix and preconcentration of trace metals}

It has been demonstrated that $\gamma$-aminobutyrohydroxamate resins can eliminate alkali and alkaline earth metals efficiently [15-17], a great advantage in sea water analysis. Elimination of $\mathrm{Na}, \mathrm{K}, \mathrm{Mg}$ and $\mathrm{Ca}$ is still necessary, especially of $\mathrm{Mg}$ and $\mathrm{Ca}$, because of interference in the chromatography and in the determination by postcolumn derivatization with PAR. For the experiment, the P13 resin concentrator $(10 \times 4 \mathrm{~mm}$ i.d. $)$ was conditioned with a mixture of sodium acetate $(1 \mathrm{mM}, \mathrm{pH} 5.5,25 \mathrm{ml})$ and potassium nitrate $(10 \mathrm{mM})$ until the baseline was stable. Siriraks and Kingston reported that, ammonium acetate at $\mathrm{pH}$ 5.0-5.5 can be used to elute $\mathrm{Na}, \mathrm{K}, \mathrm{Ca}$ and $\mathrm{Mg}$ selectively from an iminodiacetic acid resin column 


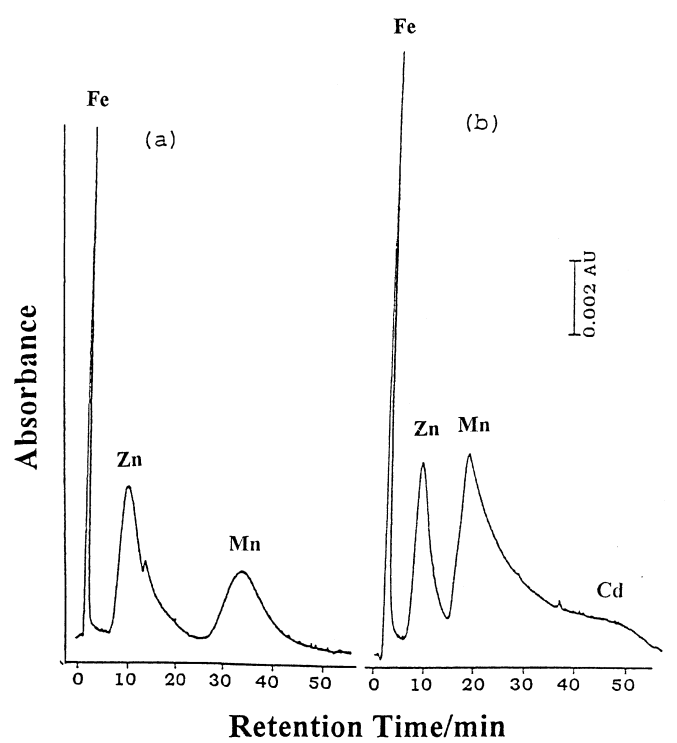

Fig. 1. Matrix effect on separation of metal ion mixture. Stationary phase: N-methyl-P13 resin $(250 \times 3 \mathrm{~mm}$ i.d. $)$; Eluent: oxalic acid ( $3 \mathrm{mM}, \mathrm{pH} 4.0)$; Detection: PAR $\left(3 \times 10^{-5} \mathrm{M}\right)$ in ammoniaammonium chloride buffer $(0.2 \mathrm{M}, \mathrm{pH} 10), \lambda_{\max }=495 \mathrm{~nm}$; Sample: $\mathrm{Cd}\left(4.4 \mu \mathrm{g} \mathrm{ml}^{-1}\right)-\mathrm{Fe}$ (III) $\left(0.6 \mu \mathrm{g} \mathrm{ml}^{-1}\right)-\mathrm{Mn}$ (II) $\quad\left(1.0 \mu \mathrm{g} \mathrm{ml}^{-1}\right)$ $\mathrm{Zn}\left(0.7 \mu \mathrm{g} \mathrm{ml}^{-1}\right)$. $\mathrm{AU}=$ absorbance. (a) in pure water $(\mathrm{Cd}$ not shown within the test time), (b) in sea water.

[9]. Only pure water $(50 \mathrm{ml})$ was needed for the elution of weakly bound alkaline earth metal ions from the P13 column [4]. This is strong evidence that P13 is a highly selective resin for transition metal ions in the complex matrix sample. However, it was found that pure water greatly increased the column pressure due to swelling of the resin. So, the subsequently experiments were performed with potassium nitrate (1 mM).

For the determination of the breakthrough capacity of the chelating concentrator (the P13 column), the sample was passed through it instead of the sample loop and fed straight into the detector, until a stable elevated absorbance signal was obtained. For $20 \mathrm{ng} \mathrm{ml}^{-1} \mathrm{Cd}(\mathrm{II})$, the breakthrough capacities at flow rates of $2.1,2.5 .2 .7,3.3$ and $3.5 \mathrm{ml} \mathrm{min}^{-1}$ were measured. Complete retention of the analyte was obtained up to $3.5 \mathrm{ml} \mathrm{min}^{-1}$ and the breakthrough capacity is $>8 \mathrm{mg}$ for the tested amount. This means that a large volume of samples can be passed through the column without exceeding the breakthrough volume, or losing cadmium. At a flow rate of
Table 2

Recovery of $10 \mu \mathrm{g}$ of transition metals on a $\gamma$-aminobutyrohydroxamate resin column ${ }^{\mathrm{a}}$

\begin{tabular}{lcl}
\hline Metal & \multicolumn{2}{l}{ Recovery $(\%)$} \\
\cline { 2 - 3 } & Pure water & Sea water \\
\hline $\mathrm{Cd}$ & 94 & - \\
$\mathrm{Co}$ & 101 & 99 \\
$\mathrm{Cu}$ & 91 & 75 \\
$\mathrm{Ni}$ & 97 & 54 \\
$\mathrm{Zn}$ & 91 & 100 \\
\hline
\end{tabular}

${ }^{\text {a }}$ Concentration factor: $\gamma$-aminobutyrohydroxamate resin (column dimension: $10 \times 4 \mathrm{~mm}$ i.d.; particle size: $230-325$ mesh; $8 \%$ cross linking). Sample concentration: $20 \mathrm{ng} \mathrm{ml}^{-1}$ for each metal.

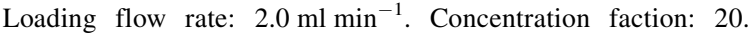
Stripping solution: oxalic acid $(0.05 \mathrm{M}, \mathrm{pH}$ 3.0). Analytical column: Dionex CS-5 column. Eluent: oxalic acid $(0.03 \mathrm{M}$, pH 4.50. Detection: PAR $\left(6 \times 10^{-5} \mathrm{M}\right)$ in ammonia-ammonium chloride buffer (0.3 M, pH 10), at $495 \mathrm{~nm}$.

$1 \mathrm{ml} \mathrm{min}{ }^{-1}$, the breakthrough volumes are 180 and $15 \mathrm{ml}$, and overloading, for $0.2 \mu \mathrm{g} \mathrm{ml}^{-1}, 0.5 \mu \mathrm{g} \mathrm{ml}^{-1}$ and $2 \mu \mathrm{g} \mathrm{ml}^{-1} \mathrm{Cd}(\mathrm{II})$ samples, respectively.

The concentrated metal ions were eluted and separated by the Dionex CS-5 column with the mobile phase of oxalic acid. Table 2 gives the recoveries of metal ion mixture from $25 \mathrm{ml}$ of pure water and sea water spiked with $20 \mathrm{ng} \mathrm{ml}^{-1}$ of each metal ion. The results indicate that, the recoveries from sea water are poorer than those from pure water, especially, for cadmium(II), due to the formation of cadmium-chloride species. However, by use of a factor for these quantitative results, determination of $\mathrm{Cu}, \mathrm{Co}, \mathrm{Ni}$ and $\mathrm{Zn}$ in sea water is feasible.

It is important to use a high purity reagent and water. Any trace metals in the reagents will be concentrated as a blank and subsequently eluted with the sample. The system blank results from contamination of the chelation concentration reagents and the system. In addition, analytes were prepared in a clean room (class 100) prior to use. For high concentration power, a P13 guard column was employed to purify all possible contaminants in the chromatographic system.

\subsection{Optimization of the separation conditions}

Among the hydroxamate resin phase, $\mathrm{P} 13$ resin has the highest complexing ability and the least interference from other chelating agents that coexist with the 
Table 3

Capacity factors for various metal ions at different eluent condition ${ }^{\mathrm{a}}$

\begin{tabular}{|c|c|c|c|c|c|c|c|}
\hline \multirow[t]{2}{*}{ Eluent } & \multicolumn{7}{|l|}{$\mathrm{K}^{\prime}$} \\
\hline & $\mathrm{Cd}$ & Co & $\mathrm{Cu}$ & $\mathrm{Fe}$ & $\mathrm{Mn}$ & $\mathrm{Ni}$ & $\mathrm{Zn}$ \\
\hline \multicolumn{8}{|c|}{$\overline{\text { Oxalate (pH 4) }}$} \\
\hline $3 \mathrm{mM}$ & - & 4.65 & 3.60 & 0.43 & 14.33 & 8.47 & 3.70 \\
\hline $6 \mathrm{mM}$ & - & 1.44 & 0.73 & 0.34 & 4.80 & 1.27 & 1.13 \\
\hline $10 \mathrm{mM}$ & 33.53 & 0.79 & 0.55 & 0.29 & 2.15 & 0.79 & 0.75 \\
\hline $20 \mathrm{mM}$ & 7.27 & - & - & - & - & - & - \\
\hline \multicolumn{8}{|c|}{ Oxalate (pH 3.5) } \\
\hline $2 \mathrm{mM}$ & - & 3.70 & 3.53 & 0.45 & 9.00 & 3.21 & 2.49 \\
\hline $3 \mathrm{mM}$ & 37.00 & 2.51 & - & 0.53 & 5.93 & 3.02 & 2.31 \\
\hline $4 \mathrm{mM}$ & 24.20 & 1.45 & 1.08 & 0.43 & 4.07 & 1.49 & 0.64 \\
\hline \multicolumn{8}{|c|}{ Oxalate (3 mM)-ethylene diamine ( $\mathrm{pH} 4)$} \\
\hline $0.5 \mathrm{mM}$ & - & 1.79 & 1.88 & 0.39 & 4.65 & 2.97 & 1.93 \\
\hline $1 \mathrm{mM}$ & - & 1.72 & - & 0.35 & 3.73 & 2.70 & 1.70 \\
\hline \multicolumn{8}{|c|}{ Oxalate (3 mM)-tartrate (pH 4) } \\
\hline $2 \mathrm{mM}$ & - & 3.66 & 5.47 & 0.35 & 11.87 & 11.67 & 3.23 \\
\hline \multicolumn{8}{|c|}{ Oxalate (2 mM)-ethylene diamine (pH 4) } \\
\hline $0.5 \mathrm{mM}$ & - & 2.68 & 4.80 & 0.38 & 7.13 & 6.00 & 2.89 \\
\hline \multicolumn{8}{|c|}{ Oxalate (2 mM)-tartrate ( $\mathrm{pH} 3.5)$} \\
\hline $1 \mathrm{mM}$ & 25.33 & 1.56 & 5.80 & 1.51 & 3.60 & 1.80 & 1.45 \\
\hline $5 \mathrm{mM}$ & - & 0.90 & - & 0.41 & - & - & 0.78 \\
\hline \multicolumn{8}{|c|}{ Tartrate $(\mathrm{pH} 4)$} \\
\hline $3 \mathrm{mM}$ & - & - & - & - & 35.33 & - & 6.27 \\
\hline $20 \mathrm{mM}$ & - & 2.67 & - & - & - & 7.13 & 3.11 \\
\hline \multicolumn{8}{|c|}{ Citrate (pH4) } \\
\hline $10 \mathrm{mM}$ & - & 13.74 & - & - & - & 6.35 & - \\
\hline $20 \mathrm{mM}$ & - & 5.12 & - & - & 9.00 & 3.22 & 7.53 \\
\hline $30 \mathrm{mM}$ & - & 1.49 & - & - & - & 2.07 & 4.17 \\
\hline
\end{tabular}

${ }^{a} \gamma$-Aminobutyrohydroxamate resin column (particle size: 230-325 mesh; $8 \%$ cross linking; $250 \times 3$ mm i.d.).

sample. Various concentration of oxalate, citrate, tartrate, ethylene diamine alone or in any combination were evaluated for the elution of metal ion mixtures (Table 3). Unexpectedly, the retention time decreased in the order citric acid>tatric acid $>$ oxalic acid. In other words, the elution power of citric acid is the worst among the reagents. Citrate has the highest affinity for the metal ions (Table 1). However, at $\mathrm{pH}<4$, molecular forms are predominant for citric acid, while ionic acid forms are the major component for oxalic acid. Therefore, it gives rise to the phenomena mentioned. We also found that the increase in the concentration of complexing agents lowers the retention time of metal ions. The separation efficency of metal ions is governed predominantly by the competitive reaction between the chelating groups immoblized on the stationary phase and the complexing agent in the mobile phase (see Table 1) $[15,16,18,20]$. Oxalate was found to be a particularly useful eluent among the complexing agents.

Despite the great concentration factor of the P13 resin column, the success of using it simultaneously as a concentrator $(10 \times 4 \mathrm{~mm}$ i.d. $)$ and separator $(250 \times 3 \mathrm{~mm}$ i.d. $)$ was hampered by the on-line absorbance detection. In addition, the conditions that are effective for eluting metals from the concentrator do not comply with the loading conditions of the separator column. Hence, an appropriate combination was the use of $O$-methyl-P13 resin, a non-replaceable hydrogen ligand, simultaneously, as concentrator and separator. By gradient elution with oxalic acid $(\mathrm{pH} 4.5)$ with a concentration range from $5 \mathrm{mM}$ to $0.01 \mathrm{M}$ in $30 \mathrm{~min}$, then $0.01-0.04 \mathrm{M}$ in $15 \mathrm{~min}$, the separation of $\mathrm{Cd}(\mathrm{II}), \mathrm{Co}(\mathrm{II}), \mathrm{Cu}(\mathrm{II}), \mathrm{Fe}(\mathrm{III}), \mathrm{Mn}(\mathrm{II})$, $\mathrm{Ni}(\mathrm{II})$ and $\mathrm{Zn}$ (II) gave seven peaks. However, a baseline drift was observed. This is undesirable for quan- 


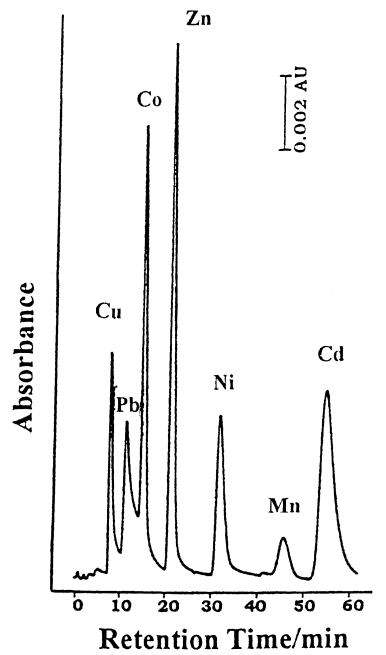

Fig. 2. On-line preconcentration and separation of metal ion mixture in pure water. Concentrator: P13 resin $(10 \times 4 \mathrm{~mm}$ i.d.); Conditioning solution: potassium nitrate $(0.01 \mathrm{M})$ in sodium acetate buffer ( $1 \mathrm{mM}$, pH 5.5); Sample solution: $25 \mathrm{ml}$ of $\mathrm{Cd}(\mathrm{II})$ (4.00 ng ml${ }^{-1}$ ) and $\mathrm{Co}(\mathrm{II})-\mathrm{Cu}(\mathrm{II})-\mathrm{Mn}$ (II)-Ni(II)-Pb(II)-Zn(II) (1.00 $\mathrm{ng} \mathrm{ml}^{-1}$ each); Loading flow rate: $2.0 \mathrm{ml} \mathrm{min}^{-1}$; Analytical column: Dionex CS-5 $(250 \times 4.6 \mathrm{~mm}$ i.d. $)$; Eluent: oxalic acid $(0.03 \mathrm{M}, \mathrm{pH} 2.6)$; Detection: PAR $\left(6 \times 10^{-5} \mathrm{M}\right)$ in ammoniaammonium chloride buffer $(0.3 \mathrm{M}, \mathrm{pH} 10)$ at $495 \mathrm{~nm}$.

titation. Attempts were made to alleviate this limitation by using P13 resin concentrator combined with a commercially available Dionex CS-5 separator. Pyridine-2,6-dicarboxylic acid (PDCA) (3 mM, pH 4.5) could be used as the mobile phase with the Dionex CS5 separator. But a lower separation efficiency was displayed when a P13 concentrator and CS-5 separator were connected and potassium nitrate was used as the eliminator. So, oxalic acid was employed as the mobile phase instead of PDCA.

The higher $\mathrm{pH}$ of oxalic acid ( $\mathrm{pH} 4.5)$ gives serious peak overlapping $\left(t_{\mathrm{R}}=5 \mathrm{~min}\right)$ for the sea water matrix and $\mathrm{Cd}(\mathrm{II}), \mathrm{Cu}(\mathrm{II})$ and $\mathrm{Zn}(\mathrm{II})$, while oxalic acid at $\mathrm{pH}$ 2.6 gives a complete separation of metal ions and sea water matrix. Hence, a lower $\mathrm{pH}$ oxalic acid solution was recommended as the mobile phase. The eluted metal ions are derivatized with 4-(2-pyridylazo)resorcinol and then detected at $495 \mathrm{~nm}$. Fig. 2 shows the on-line preconcentration and separation of metal ions in pure water. The calibration graphs for the determination of metal ion mixtures are summarized in Table 4. The established method shows good peak height linearity for $\mathrm{Co}(\mathrm{II}), \mathrm{Cu}(\mathrm{II}), \mathrm{Mn}(\mathrm{II}), \mathrm{Ni}(\mathrm{II})$,
Table 4

Determination of metal ion mixtures using chelation ion chromatography $^{\mathrm{a}}$

\begin{tabular}{lll}
\hline Metal ion & Least squares linear equation & $\begin{array}{l}\text { Detection } \\
\text { limit }\left(\mathrm{ng} \mathrm{ml}^{-1}\right)\end{array}$ \\
\hline $\mathrm{Cd}(\mathrm{II})$ & $y=0.786 x+0.135(r=0.9989)$ & 1.2 \\
$\mathrm{Co}(\mathrm{II})$ & $y=7.870 x-1.614(r=0.9992)$ & 0.4 \\
$\mathrm{Cu}(\mathrm{II})$ & $y=3.330 x+0.560(r=0.9952)$ & 0.5 \\
$\mathrm{Mn}(\mathrm{II})$ & $y=0.642 x+0.221(r=0.9930)$ & 0.4 \\
$\mathrm{Ni}(\mathrm{II})$ & $y=2.647 x-1.073(r=0.9844)$ & 0.8 \\
$\mathrm{~Pb}(\mathrm{II})$ & $y=0.217 x+0.997(r=0.9934)$ & 2.0 \\
$\mathrm{Zn}$ (II) & $y=9.139 x-0.046(r=0.9929)$ & 0.3
\end{tabular}

${ }^{\text {a }}$ Concentrator: $\gamma$-aminobutyrohydroxamate resin (particle size: 230-325 mesh, $8 \%$ cross linking; $10 \times 4 \mathrm{~mm}$ i.d.); Condition solution: $\mathrm{KNO}_{3}(0.01 \mathrm{M})$ in acetate buffer $(1 \mathrm{mM}, \mathrm{pH} 5.5)$; Samples solution: $25 \mathrm{ml}$; Loading flow rate: $2.0 \mathrm{ml} \mathrm{min}{ }^{-1}$, Analytical column: Dionex CS-5; Eluent: oxalic acid $(0.03 \mathrm{M}$, $\mathrm{pH}$ 2.6); Detection: at $495 \mathrm{~nm}$ with PAR $\left(6 \times 10^{-5} \mathrm{M}\right)$ in ammoniaammonium chloride buffer $(0.3 \mathrm{M}, \mathrm{pH} 10) . y=$ peak height (absorbance), $x=$ concentration of metal ion $\left(\mathrm{ng} \mathrm{ml}^{-1}\right) ; 6$ data points for each equation.

$\mathrm{Pb}$ (II) and $\mathrm{Zn}$ (II) ranging from 0.5 to $10 \mathrm{ng} \mathrm{ml}^{-1}$ and for Cd(II) from 2 to $40 \mathrm{ng} \mathrm{ml}^{-1}$. The correlation coefficients are $>0.99$. The detection limit, defined as three times the standard deviation of the response for the lowest concentration $(n=5)$ in the chromatogram for $\mathrm{Co}(\mathrm{II}), \mathrm{Cd}(\mathrm{II}), \mathrm{Cu}(\mathrm{II}), \mathrm{Mn}$ (II), $\mathrm{Ni}(\mathrm{II}), \mathrm{Pb}$ (II) and $\mathrm{Zn}(\mathrm{II})$, was $0.4,1.2,0.5,0.4,0.8,2.0$ and $0.3 \mathrm{ng} \mathrm{ml}^{-1}$, respectively. Fig. 3 shows, the chromatogram of a sea water sample from the coast of the western Pacific Ocean spiked with $1 \mathrm{ng} \mathrm{ml}^{-1}$ of each metal ion. The background signal decreased with increasing volume of matrix eliminator up to $25 \mathrm{ml}$. A significant difference in the chromatograms between Figs. 2 and 3 was found, for which the sensitivities of lead and cadmium in sea water are rather small in comparison with that in pure water.

\subsection{Measurement of selected elements in a standard reference material}

To establish whether the proposed method could be applicable to biological samples, a standard reference material (SRM): Oyster Tissue (NIST, SRM 1566a) was studied. Only copper and zinc determinations could be achieved for the digested sample without any pretreatment. With a concentrator, a $10 \mathrm{ml}$ aliquot solution from a $0.1 \mathrm{~g}$ digested sample in $100 \mathrm{ml}$ pure water gave the chromatogram shown in Fig. 4. With a 


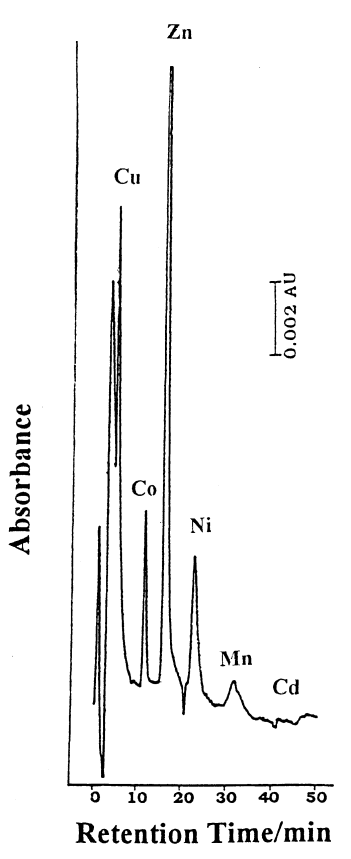

Fig. 3. On-line preconcentration and separation of metal ion mixture in sea water. Concentrator: P13 resin $(10 \times 4 \mathrm{~mm}$ i.d.); Conditioning solution: potassium nitrate $(0.01 \mathrm{M})$ in sodium acetate buffer ( $1 \mathrm{mM}, \mathrm{pH} 5.5)$; Sample solution: $25 \mathrm{ml}$ sea water spiked with a mixture of $\mathrm{Cd}(\mathrm{II})\left(4.00 \mathrm{ng} \mathrm{ml}^{-1}\right)$ and $\mathrm{Co}(\mathrm{II})-\mathrm{Cu}(\mathrm{II})-$ $\mathrm{Mn}(\mathrm{II})-\mathrm{Ni}(\mathrm{II})-\mathrm{Pb}(\mathrm{II})-\mathrm{Zn}$ (II) (1.00 $\mathrm{ng} \mathrm{m}^{-1}$ for each); Loading flow

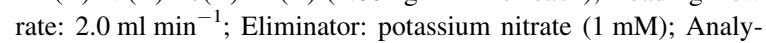
tical column: Dionex CS-5 $(250 \times 4.6 \mathrm{~mm}$ i.d. $)$; Eluent: oxalic acid (0.03 M, pH 2.6); Detection: PAR $\left(6 \times 10^{-5} \mathrm{M}\right)$ in ammoniaammonium chloride buffer $(0.3 \mathrm{M}, \mathrm{pH} 10)$ at $495 \mathrm{~nm}$.

Table 5

Trace elements in oyster tissue (NIST SRM 1566a)

\begin{tabular}{lll}
\hline Element & $\begin{array}{l}\text { Certified concentration } \\
\left(\mu \mathrm{g} \mathrm{g}^{-1}\right)\end{array}$ & $\begin{array}{l}\text { Concentration } \\
\text { found }^{\mathrm{a}}\left(\mu \mathrm{g} \mathrm{g}^{-1}\right)\end{array}$ \\
\hline $\mathrm{Cd}$ & $4.15 \pm 0.38$ & $2.67 \pm 0.23$ \\
$\mathrm{Co}$ & $0.57 \pm 0.11$ & $0.36 \pm 0.03$ \\
$\mathrm{Cu}$ & $66.3 \pm 4.3$ & $73.1 \pm 8$ \\
$\mathrm{Mn}$ & $12.3 \pm 1.5$ & $14.8 \pm 1.4$ \\
$\mathrm{Zn}$ & $8.30 \pm 57$ & $8.11 \pm 14$ \\
\hline
\end{tabular}

a Concentrator: $\gamma$-aminobutyrohydroxamate resin (particle size: 230-325 mesh, $8 \%$ cross linking; $10 \times 4 \mathrm{~mm}$ i.d.); Condition solution: $\mathrm{KNO}_{3}(0.01 \mathrm{M})$ in acetate buffer $(1 \mathrm{mM}, \mathrm{pH} 5.5)$; Samples solution: portion $(10 \mathrm{ml})$; of $0.1 \mathrm{~g}$ digested sample in $100 \mathrm{ml} \mathrm{H} \mathrm{H}_{2} \mathrm{O}$; Loading flow rate: $2.0 \mathrm{ml} \mathrm{min}^{-1}$; Analytical column: Dionex CS-5; Eluent: oxalic acid (0.03 M, pH 2.6); Detection: at $495 \mathrm{~nm}$ with PAR $\left(6 \times 10^{-5} \mathrm{M}\right)$ in ammonia-ammonium chloride buffer $(0.3 \mathrm{M}, \mathrm{pH} 10)$. Results are mean \pm standard deviation $(n=3)$.

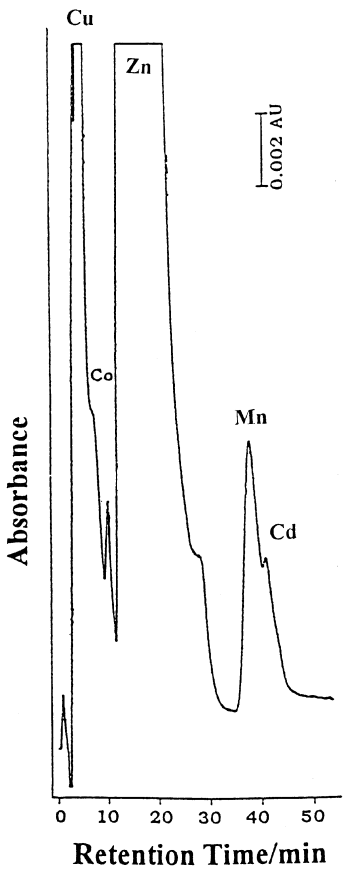

Fig. 4. Separation of transition metals dissloved from oyster tissue (NIST SRM 1566a) digested sample using chelation ion chromatography. Concentrator: P13 resin $(10 \times 4 \mathrm{~mm}$ i.d.); Conditioning solution: potassium nitrate $(0.01 \mathrm{M})$ in sodium acetate buffer (1 mM, pH 5.5); Sample solution: $10 \mathrm{ml}$ aliquot solution of digested sample in $100 \mathrm{ml}$ pure water; Loading flow rate: $2.0 \mathrm{ml} \mathrm{min}{ }^{-1}$; Eliminator: potassium nitrate $(0.001 \mathrm{M})$; Analytical column: Dionex CS-5 $(250 \times 4.6 \mathrm{~mm}$ i.d. $)$; Eluent: oxalic acid $(0.03 \mathrm{M}, \mathrm{pH} 2.6)$; Detection: PAR $\left(6 \times 10^{-5} \mathrm{M}\right)$ in ammoniaammonium chloride buffer $(0.3 \mathrm{M}, \mathrm{pH} 10)$ at $495 \mathrm{~nm}$.

standard addition method, the results for the determination of five elements in oyster tissue are presented (Table 5). Good agreement was obtained between the measured results and certified values for most of the elements determined in the SRM, except for cadmium and cobalt. These results clearly indicate that the prepared column was effective as a concentrator for biological matrices. Since, there are serious overlaps between $\mathrm{Mn}$ and $\mathrm{Cd}, \mathrm{Cu}$ and $\mathrm{Co}$, more efficient separation conditions are necessary for the accurate determination of cadmium and cobalt ions.

\section{Conclusions}

In recent years, the demand for lower limits of detection for elements with environmental and biolo- 
gical significance has been greater than ever before. The use of stationary phases with higher selectivities for transition metal ions facilitates the solution of an important problem often encountered in the ion chromatography of environmental or biological samples. However, the gain in selectivity is achieved at the cost of increased analysis time. Further, the lack of commercially available chelating columns also hinders the application of chelation ion chromatography to routine analysis. In this work, three kinds of $\gamma$-aminobutyrohydroxamate resin with a hydrophilic polymer matrix were employed to be the stationary phases of chelation ion chromatography. All of them are highly promising. Nevertheless, improvement of the separation efficiency is needed. This could be possible with higher cross linking and smaller particle size of the chelating resin. Although, the applicability of the resin column simultaneously as both concentrator and separator was limited by detection using the postcolumn spectrophotometric system, it is feasible if inductively coupled plasma atomic emission or mass spectrometry are introduced as the detection system.

\section{Acknowledgements}

We thank the National Science Council of the Republic of China (Taiwan) for financial support. The authors wish also to thank Prof. S.C. Pai, Institute of Oceanography, National Taiwan University, for collection of sea water samples.

\section{References}

[1] Y. Inoue, H. Kumagai, Y. Shimomura, T. Yokoyama, T.M. Suzuki, Anal. Chem. 68 (1996) 1517.

[2] S. Sundd, B.B. Prasad, Talanta 42 (1995) 1395.

[3] B. Paull, P. Jones, Chromatogr. 42 (1996) 528.

[4] C.Y. Liu, N.M. Lee, T.H. Wang, Anal. Chim. Acta 337 (1997) 173.

[5] R. Caprioli, S. Torcini, J. Chromatogr. 640 (1993) 365.

[6] N. Cardellicchio, S. Cavalli, J.M. Riviello, J. Chromatogr. 640 (1993) 207.

[7] A.R. Timerbaev, G.K. Bonn, J. Chromatogr. 640 (1993) 195.

[8] P. Jones, O.J. Challenger, S.J. Hill, N.W. Barnett, Analyst 117 (1992) 1447.

[9] A. Siriraks, H.M. Kingston, J.M. Riviello, Anal. Chem. 62 (1990) 1185.

[10] P. Jones, M. Foulkes, B. Paull, J. Chromatogr. A. 673 (1994) 173.

[11] B. Paull, M. Foulkes, P. Jones, Analyst 119 (1994) 937.

[12] B. Paull, M. Foulkes, P. Jones, Anal. Proc. Include. Anal. Commun. 31 (1994) 209.

[13] D. Cagniant, Complexation Chromatography, Marcel Dekker, New Yok, 1992.

[14] P.N. Nesterenko, P. Jones, J. Chromatogr. A. 770 (1997) 129.

[15] C.Y. Liu, M.J. Chen, N.M. Lee, H.C. Hwang, S.T. Jou, J.C. Hsu, Polyhedron 11 (1992) 551.

[16] N.M. Lee, C.Y. Liu, J. Chin. Chem. Soc. 42 (1995) 521.

[17] N.M. Lee, C.Y. Liu, J. Chin. Chem. Soc. 43 (1996) 473.

[18] A.E. Martell, R.M. Smith, Critical Stability Constants, Plenum, New York, 1980.

[19] J. Buffle, Complexation Reactions in Aquatic Systems, Horwood, Chichester, 1988.

[20] J.A. Dean, Lange's Handbook of Chemistry, McGraw-Hill, New York, 1985. 